\title{
A autora e leitora Renata Pallottini
}

Profa. Dra. Maria Cristina Castilho Costa

Livre-docente em Ciências da Comunicação pela Escola de Comunicações e Artes, da Universidade de São Paulo. Professora associada da Universidade de São Paulo, presidente da Comissão de Pesquisa da ECA/USP, coordenadora do Curso de Especialização Lato Sensu Educomunicação - comunicação, mídias e educação. Coordenadora do NPCC (Núcleo de Pesquisa em Comunicação e Censura da USP) e do Projeto Temático Comunicação e Censura - Análise teórica e documental de processos censórios a partir do Arquivo Miroel Silveira, da ECA/USP, com apoio da FAPESP.

E-mail: criscast@usp.br

Resumo: A partir da reflexão a respeito de obra da escritora e poetisa Renata Pallottini, o texto reflete sobre a influência do público no desenvolvimento da obra cultural artística, traço fortalecido pela indústria cultural. Com base nas leituras de Georges Simenon, a autora escreve um romance policial - Chez Mme. Maigret - no qual a protagonista é a esposa do famoso inspetor de polícia da França Jules Maigret. Assim Pallottini dá vida à personagem e participa do universo literário de Simenon.

Palavras-chave: Indústria cultural, literatura, obra aberta; arte, cultura, modernidade, pós-modernidade.
Abstract: Based on the study of the work of the writer and poet Renata Pallottini, the article discusses the influence of the public on the development of artistic and cultural works, consolidated by the cultural industry. Using her readings of Georges Simenon as a starting point, the author writes a detective novel named Chez Mme. Maigret, in which the main character is the wife of the famous French Police Inspector Jules Maigret. Pallottini brings the character to life and participates in Simenon's literary universe.

Keywords: Cultural industry, literature, the open work, art, culture, modernity, postmodernity.

Durante muito tempo, pensamos que o autor fosse dono exclusivo de sua obra - da história criada, do monumento erigido, da composição apresentada -, senhor absoluto dos desígnios e do destino de sua criação. O direito autoral era uma deferência àquele que deu nome ao texto, que assinou a pintura, que compôs a música e que elaborou o projeto do edifício, tornando-se responsável por tudo que se relacionasse à obra, inclusive identidade e história. A modernidade foi esse período áureo de consagração do autor/criador de textos, pinturas, músicas e projetos arquitetônicos. Ser autor enobrecia e valorizava a produção literária e artística.

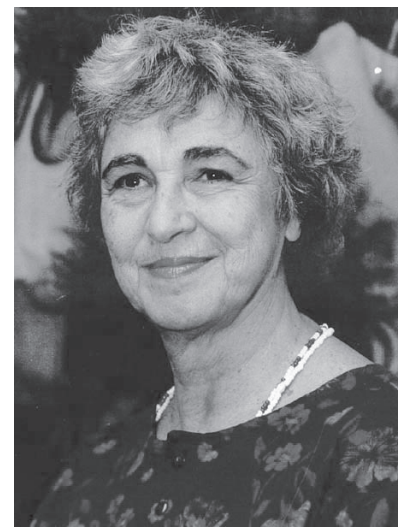

Renata Pallottini 
comunicação \& educação • Ano XVII • número 2 • jul/dez 2012

A indústria cultural, desde a implantação da imprensa periódica, foi sempre muito favorecida pelo reconhecimento e poder dos autores. Mas, por outro lado, empregando na produção cultural equipes cada vez maiores e mais recursos tecnológicos, colocou em cheque a autonomia dos autores, dissolvendo sua importância e tornando a produção cultural uma atividade cada vez mais coletiva e plural. Assim, com a massificação da arte e da cultura, a "aura" da autoria, como diria Walter Benjamin, foi se diluindo em um universo cultural povoado não só por escritores, poetas, arquitetos, urbanistas, pintores, compositores, mas também por uma produção massificada, coletiva e anônima que povoa nosso imaginário, buscando referendar nossos sonhos, nossos desejos e nossa cotidianidade. Histórias são recontadas, dramas se reproduzem em série, personagens ganham vida, disputando espaço, atenção e afetividade do público, tornando-se cada vez mais independentes de seus autores. Dessa forma desenvolve-se a cultura midiática, multiplicando-se e refletindo-se num sem número de imagens e seres que passam a fazer parte de nossa subjetividade.

Sobrevivendo a essa ampla e desmedida reprodução, boas histórias e bons personagens ganham vida própria e uma impensada emancipação em relação a seus criadores - tornam-se familiares, invadem intimidades, povoam vidas e se instalam na memória com mais nitidez do que muitas das experiências vividas, do que pessoas conhecidas, do que momentos concretamente compartilhados. Essa ideia é defendida por Néstor Garcia Canclini, entre outros autores que analisam os fenômenos da cultura contemporânea.

Esses estudos que procuram entender o que define, emociona, influencia ou identifica o ser humano na atualidade, e que buscam avaliar a importância da autoria hoje, trazem para o centro da cena, além do autor e da obra, outro personagem - o público, aquele que parece ser o responsável pelo sentido final da obra, da história, de seu significado, assim como de sua permanência no tempo. As teorias da recepção e os estudos culturais têm ressaltado a importância do espectador, do leitor, do ouvinte, em cujo imaginário a história toma corpo, se desenvolve, se organiza e vira memória, lembrança e referência. Diante dessa constatação, o autor e a obra perdem sua importância? Não, o autor, ainda que coletivo ou anônimo, será sempre a fonte, a criação - e a obra, a mediação entre ele e o público.

Umberto Eco descreveu esse entrosamento, essa convergência que se opera entre autor, obra e público e que ele denomina de pacto ficcional. Em Seis passeios pelos bosques da ficção ${ }^{1}$, mostra como a ficção se realiza através desse pacto - como autor e espectador (ou leitor) se deslocam para um campo de probabilidades, rompendo as amarras com o aqui/agora e abrindo espaço para o novo, para o inusitado, para a criação ficcional.

Assim, tanto a ciência como a produção artística contemporânea valorizam

1. ECO, Humberto. Seis passeios pelos bosques da ficção. São Paulo: Companhia das Letras, 1999. cada vez mais o leitor, o espectador, o receptor, num respeito cerimonioso que o reconhece como apreciador e parceiro, a partir do qual se elaboram a ficção, as narrativas e os romances. Mas, se autor e receptor se aproximam, o ponto de encontro entre eles continua a ser a obra e, muitas vezes, o personagem 
como a fronteira que ainda os distingue e separa e que, graças ao esforço de ambos, adquire vida, força, caráter e destino.

Anatol Rosenfeld afirma, nesse sentido, que a personagem é o elemento que se impõe entre autor e leitor, transformando, definitivamente, a obra em ficção.

Essas reflexões, com as quais iniciei o presente texto, foram inspiradas pela leitura do último livro de Renata Pallottini - Chez Mme. Maigret ${ }^{2}$. Renata é poetisa, dramaturga, autora de roteiros para programas de televisão e estudiosa de telenovela, mostrando-se sempre talentosa, culta, divertida e emocionante. Além de tudo isso, é leitora contumaz de Georges Simenon, ele também um escritor profícuo e plural, tendo acompanhado grande parte das aventuras investigativas de seu principal personagem - o inspetor de polícia da França Jules Maigret. Corpulento, apreciador da boa comida e de um bom trago, fumante de um bom cachimbo e reconhecido por sua perícia no desvendar de crimes da primeira metade do século XX, ele tem por característica também ser um bom ouvinte, saber compreender as pessoas e suas motivações e desvendar os crimes a partir de uma criativa intuição. Sem usar armas ou força, esse famoso personagem cheio de humanidade mostra-se reservado, empenhado em seu trabalho e capaz de elucidar os motivos que levam pessoas à transgressão.

Mme. Maigret é a companheira de um longo casamento, no qual o inspetor se instalou como em seu escritório ou no bar onde bebe drinques acompanhado de amigos. Fiel à esposa, mas sem arroubos sentimentais, Maigret tem o casamento perfeito para a vida que escolheu para si - contando com a companhia solícita de uma mulher exemplar que lhe garante um lar aconchegante e sem surpresas (agradáveis ou não).

Mas Renata Pallottini é uma leitora contemporânea, e sabe do poder que hoje tem o público de quem depende não só o sentido da narrativa, como o sucesso das obras culturais e artísticas. E, como uma leitora tão intuitiva quanto o inspetor Maigret, Pallottini se apodera dos personagens e com eles tece o seu próprio romance - uma história contada pela Senhora Maigret que, interessada em um dos últimos casos que seu marido tem para elucidar, acaba se envolvendo nos meandros da história, o que mobiliza suas próprias paixões e anseios. Mme.

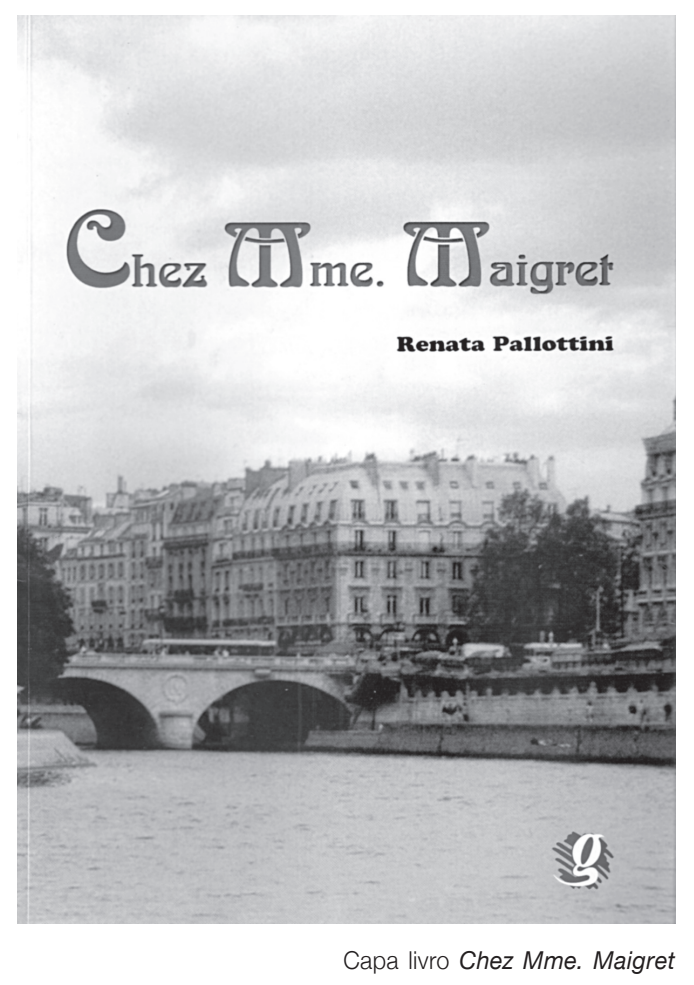

2. PALLOTTINI, Renata. Chez Mme. Maigret. São Paulo: Global, 2011. 
comunicação \& educação • Ano XVII • número 2 • jul/dez 2012

Maigret, uma mulher que vive para o bem-estar do marido e para as atividades do lar, se vê frente a frente com o intrincado caso de um jovem encontrado morto no Rio Sena, perpassado por uma lança antiga de origem desconhecida. Como nos romances policiais de Simenon, ao jovem assassinado estão ligados outros personagens que vão desfilando em cena: uma mulher estrangeira que se apresenta como sua mãe, um homem que se diz seu primo e outros personagens igualmente misteriosos. Mas, de forma diferente do que teria feito em outras ocasiões, a esposa do inspetor sai de sua habitual discrição e vai se enrolando nos nós dessa trama, atraída inicialmente pela misteriosa origem da lança utilizada no crime.

$\mathrm{O}$ envolvimento de Mme. Maigret no misterioso caso não ajuda em quase nada a sua elucidação, mas faz com que ela vá percebendo aos poucos o distanciamento que existe entre ela e o marido, o quanto sua vida corre paralela à dele e quão insignificantes são seus desejos, pensamentos e paixões para o companheiro. A esposa de Maigret não elucida o crime em questão, mas faz descobertas profundas sobre sua própria sensibilidade. O que acontecerá a partir daí - uma verdadeira peripécia na estrutura narrativa de Simenon - mostra como a leitora se transforma em autora e articula um destino sem volta para um personagem de ficção criado por um outro autor.

A reviravolta imaginada por Pallottini coloca, por sua vez, grandes questões aos seus próprios leitores: como o sagaz personagem não foi capaz de perceber os anseios de sua própria esposa? Como ele, tão conhecedor da alma humana, não intuiu o mundo de anseios e paixões que se escondia por sob a capa de uma aparente brandura? Como, tão dedicado à defesa das vítimas, acabava por deixar de lado, em sua própria casa, a defesa da companheira? Então, nem mesmo os maridos intuitivos e inteligentes conseguem desvendar a alma feminina? Essas respostas a autora não nos dá, ela as deixa para nós, seus leitores, para que nós, assim como ela, possamos nos apropriar da narrativa e com ela tecer nosso próprio romance. Esse é o verdadeiro romance contemporâneo - com poucas explicações, mas com muitas sutilezas e sugestivos mistérios, uma obra que não termina, mas migra, se reinventa e se torna intertextual. 